\title{
First report of tobacco mosaic virus infecting Geranium thunbergii in Korea
}

\author{
Hwi-Won Jeong ${ }^{1} \cdot$ Seon-Min Go ${ }^{1} \cdot$ Hyo-Jeong Lee ${ }^{1} \cdot$ Nam-Yeon Kim $^{1} \cdot$ Mi-Ri Park ${ }^{2} \cdot$ Rae-Dong Jeong $^{1}$
}

Received: 18 September 2018 / Accepted: 23 February 2019 / Published online: 12 March 2019

(C) Società Italiana di Patologia Vegetale (S.I.Pa.V.) 2019

Keywords Geranium thunbergii $\cdot$ Korea · Tobacco mosaic virus

Geranium thunbergii (Family Geraniaceae) forms a component of several popular folk medicines in Asia, including a traditional antidiarrheal drug. During a survey in July 2018, viral infection-like symptoms, including mosaic, mottling, and foliage discoloration were observed on the leaves of G. thunbergii in a farm located in Naju, Korea. Twenty symptomatic leaves were selected and analyzed by DAS-ELISA using polyclonal antibodies against cucumber mosaic virus, pepper mottle virus, tobacco mosaic virus (TMV), and tomato mosaic virus (Agdia, Elkhart, IN, U.S.A). None of the samples reacted with any of the antisera, except with that against TMV. To further confirm TMV infection, RT-PCR was performed using TMV-specific primers designed from a highly conserved region of the coat protein $(\mathrm{CP})$ gene $\left(5^{\prime}\right.$ - ATGTCTTACAGTAT CACTACTCC-3' and 5'- TCAAGTTGCAGGACCAGAGG T-3') (Choi et al. 2009). PCR products of the expected size (462 bp) were amplified, and then cloned and sequenced. BLAST analysis of the primer-trimmed resulting sequence (LC417449; 436 bp) showed 99\% identity with the CP gene of several TMV isolates of Vicia faba (AJ011933), Capsicum annuum (KT923121), Solanum melongena (AY360447), Solanum lycopersicum (KC007531), and Glycine max

Mi-Ri Park

mrpark@cpri.re.kr

$\triangle$ Rae-Dong Jeong

jraed2@jnu.ac.kr

1 Department of Applied Biology, Institute of Environmentally Friendly Agriculture, Chonnam National University, Gwangju 61185, South Korea

2 Division of Plasma Application R\&BD, Cheorwon, Plasma Research Institute, Cheorwon-gun, Kangwon-do, South Korea
(JQ895560). The virus (named TMV-Gt) caused necrotic lesions on Nicotiana rustica at 5 days post inoculation (dpi), whereas mild systemic mosaic symptoms were observed in $N$. benthamiana, N. rustica, Physalis alkekengi, and N. tabacum at 10 to 14 dpi. Symptomatic hosts tested positive for TMV by RT-PCR with the aforementioned primers. To our knowledge, this is the first report of TMV infection affecting quality of G. thunbergii in Korea.

Funding This research was financially supported by Chonnam National University (Grant No. 2016-2498) and the National Research Foundation of Korea (NRF) grant funded by the Korea government (MSIP) (No. 2017R1C1001873).

Publisher's note Springer Nature remains neutral with regard to jurisdictional claims in published maps and institutional affiliations.

\section{References}

Choi S-K, Yoon J-Y, Chung B-N (2009) Genome analysis and characterization of a tobacco mosaic virus isolate infecting balsam (Impatiens balsamina). Arch Virol 154:881-885 